\title{
ВОЛОНТЕРСКАЯ ДЕЯТЕЛЬНОСТЬ ОБУЧАЮЩИХСЯ ВУЗА: К ПРОБЛЕМЕ СУЩНОСТИ И ПЕДАГОГИЧЕСКОГО ПОТЕНЦИАЛА
}

\section{VOLUNTEER ACTIVITY OF UNIVERSITY STUDENTS: PROBLEM OF ITS ESSENCE AND PEDAGOGICAL POTENTIAL}

\section{O. Nechaeva}

Summary: The article substantiates the idea of the pedagogical potential of volunteer activity of university students. The author gives an interpretation of the concept of pedagogical potential of volunteer activity. The paper highlights and describes the components of the pedagogical potential of the volunteer activity of university students and its pedagogical functions, it is concluded that the value-semantic component of the pedagogical potential is its system-forming function.

Keywords: volunteer activity, university students, pedagogical potential of volunteer activity, system-forming function, value-semantic function.
Нечаева Ольга Михайловна

Ассистент, ФГБОУ ВО «Вологодская государственная молочнохозяйственная академия им. Н.В. Верешагина» nom010646@yandex.ru

Аннотация: В данной статье обосновывается идея педагогического потенциала волонтерской деятельности обучающихся вуза. Автор дает интерпретацию понятия «педагогический потенциал волонтерской деятельности». В работе выделяются и описываются компоненты педагогического потенциала волонетерской деятельности обучающихся вуза и его педагогические функции, делается вывод, что ценностно-смысловая составляющая педагогического потенциала является его системообразующей функцией.

Ключевые слова: волонтерская деятельность, обучающиеся вуза, педагогический потенциал волонтерской деятельности, системообразующая функция, ценностно-смысловая функция.
$\mathrm{B}$ высшем образовательном учреждение реализуются многие потребности обучающихся, а деятельность посредством волонтерской работы создает условия для саморазвития, обладает широким спектром возможностей и условиями для развития личности.

Добровольность труда при этом не предполагает хаотичного характера работы. В рамках приоритетного национального проекта «Образование» одной из задач обозначено - «Создание условий для развития наставничества, поддержки общественных инициатив и проектов, в том числе в сфере добровольчества (волонтерства)» [8], в связи с чем, создаются условия для развития добровольчества и в высших учебных заведениях страны.

Опираясь на Федеральный закон № 15 от 05.02.2018 «О внесении имений в отдельный законодательный акты Российской Федерации по вопросам добровольчества (волонтерства)» слова «доброволец» и «волонтер», а также образуемые от них слова, используются в нашем исследовании как синонимы [12].

Изучение трактовок понятий «волонтер», «волонтерская (добровольческая) деятельность» в работах Л.В.Болотовой,Л.А.Кундинской,Н.В.Маковей,М.В.Певной, Л.Е. Сикорской, Н.А. Терновой, П.Я. Циткилова $[2,6,7,9$, $10,11,13]$, с опорой на Всеобщую Декларацию Волонтеров [3], позволило дать авторское толкование понятия волонтерской деятельности, как практической деятельности, направленной на предметное решение социаль- но-значимых проблем, осуществляемой без принуждения и оказывающей социализирующее влияние на субъект деятельности.

Проведенные исследования Л.А. Кудринской показали, что добровольчество сегодня - в основном молодежное движение $(91 \%$ - подростки и молодежь в возрасте 14-20 лет), представленное обучающимися учебных заведений. На сегодня это наиболее экономически свободная группа, поскольку ее базовые, прежде всего, материальные потребности обеспечиваются родителями, что дает ее участникам возможность безвозмездно осуществлять добровольческую деятельность [6].

Наше исследование посвящено педагогическому потенциалу волонтерской деятельности обучающихся вуза, то есть охватывает студенческий периода жизни человека. С точки зрения возрастной психологии «студенчество» - это период жизни человека (17 лет - 23 года), который приходится в основном на период «юности», где ведущим типом деятельности становится учебно-профессиональная. К новообразованиям юности И.С. Кон относит развитие самостоятельного логического мышления, образной памяти, индивидуального стиля умственной деятельности, интереса к научному поиску [5].

По результатам исследовательской группы под руководством Б.Г. Ананьева было установлено, что это сензитивный период для развития основных социогенных потенций человека. На данном этапе происходит фор- 
мирование профессиональных и гражданских качеств будущего специалиста, развитие его профессиональных способностей, происходит становление интеллекта и стабилизация характера, преобразование системы ценностных ориентаций и мотивации [1].С точки зрения Э.Ф. Зеера в данный период происходит развитие профессионально ориентированной структуры личности [4].

Таким образом, обучение в вузе становится важным периодом в жизни человека, где обучающийся проявляет свои способности, самоопределяется со стилем и образом жизни, окончательно определяются с профессиональным выбором. Следовательно, и волонтерская деятельность в данный период жизни должна быть направлена в рамках целостного педагогического процесса на получение опыта трудовой деятельности.

Понятие «педагогический потенциал» в современной педагогической литературе раскрыт достаточно широко и характеризуется, в первую очередь, наличием тех возможностей и средств, которые имеют образовательную и воспитательную направленность. Под педагогическим потенциалом волонтерской деятельности нами понимается наличие возможностей и средств, позволяющих активизировать внутренние механизмы формирования человека как гармонично развитой и социально ответственной личности. Социальная ответственность определяет феноменологию сущности педагогического потенциала.

Педагогический потенциал волонтерской деятельности обучающихся вуза является системно организованным феноменом, в структуре которого можно выделить следующие компоненты:

- аксиологический, создающий условия для формирования комплекса ценностно-смысловых ориентаций и модели поведения обучающихся;

- образовательный, способствующий формированию у студентов-волонтеров системы знаний, связанной профессиональной ориентацией;

- развивающий, обеспечивающий развитие критического мышления, умение самостоятельно принимать решения через привлечение обучающихся вуза к их участию в социально-значимых проектах;

- воспитательный, включающий воспитание у студентов-волонтеров активной гражданской позиции, формирование лидерских и нравственноэтических качеств;

- организационный, отражающий возможность для социализации обучающихся, заложенный в таких элементах материальной культуры, как организация пространства, организация труда, условия труда.

Педагогический потенциал волонтерской деятельно- сти обучающихся вуза может быть реализован в учебновоспитательном процессе через такие педагогические условия, как

- обеспечение принципа добровольности;

- целенаправленное педагогическое сопровождение волонтерской деятельности обучающихся;

- установку на долгосрочные социально-педагогические проекты.

Педагогические условия обусловлены тем, что сама волонтерская деятельность деятельность может рассматриваться как отдельный педагогический процесс, направленный на развитие личности, ее социализацию, межличностное общение и взаимодействие, самоопределение его участников, профессиональное развитие.

Анализ компонентов педагогического потенциала волонтерской деятельности обучающихся вуза позволяет выделить и систематизировать педагогические функции, где системообразующей является ценностно-смысловая функция (Таблица 1).

Таблица 1.

Педагогические функции волонтерской деятельности

\begin{tabular}{|c|c|}
\hline $\begin{array}{c}\text { Комплекс функций, как гармонич- } \\
\text { но развитой личности }\end{array}$ & $\begin{array}{c}\text { Комплекс функций, как социально- } \\
\text { ответственной личности }\end{array}$ \\
\hline $\begin{array}{l}\text { - личностно-развивающая } \\
\text { функция } \\
\text { - преобразующая функция } \\
\text { - гуманистическая функция } \\
\text { - духовно-нравственная функция } \\
\text { - инновационно-инициативная } \\
\text { функция }\end{array}$ & $\begin{array}{l}\text { - функция аутентичности } \\
\text { - интегрирующая функция } \\
\text { - рефлексивная функция } \\
\text { - функция социальной компетент- } \\
\text { ности } \\
\text { - профессиональная функция } \\
\text { - функция гражданского воспи- } \\
\text { тания }\end{array}$ \\
\hline
\end{tabular}

Рассмотрим более подробно каждую функцию.

- Так функция социальной компетентности отражает формирование опыта социализации человека.

- Сущность личностно-развивающей функции заключается в возможности реализовать свои склонности, интересы, способности.

- Профессиональная функция рассматривает осознание ценности труда и его общественной пользы, развитие профессионально важных качеств и профессиональной компетентности.

- Инновационно-инициативная функция определяет развитие деловых, инициативных, эвристических способностей студентов в процессе волонтерской деятельности, формирование активной жизненной позиции, умения разрабатывать социальные проекты и их реализовывать, брать на себя ответственность за результат своей деятельности. 
- Функция гражданского воспитания через активную гражданскую позицию, реализацию гражданских прав и обязанностей позволяет человеку получить общественное признание своих усилий.

- Функция аутентификации заключается в том, что посредством волонтерской деятельности у обучающего формируется чувство принадлежности к своему поколению, его передовой части.

- Интегрирующая функция. Добровольческая деятельность показывает обучающемуся кратчайший путь вхождения в социум активным его участником, он становится частью социокультурного процесса.

- Рефлексивная функция состоит в осознании уровня своей подготовки к жизни, открытии в себе сильных сторон качеств и свойств личности, возможный дефицит способностей. В результате человек понимает, над чем ему еще нужно работать.

- Преобразовательная функция отражает творческую роль волонтерской деятельности и ее носителя. Посредством добровольчества молодой человек преобразует среду и самого себя в ней.

- Гуманистическая функция заключается в оказании поддержки, внимания, заботы, участия и помощи отдельному человеку или отдельному учреждению, социальному партнеру; утверждении гуманных отношений в обществе. Волонтерская деятельность учит создавать атмосферу доверия, проявлять такие социальные чувства, как благожелательность, дружелюбие, отзывчивость, ответственность, терпимость, уважение, чуткость, эмпатия и другие.

- Духовно-нравственная функция отражает суть этой деятельности, которая направлена на утверждение добра, доверия, справедливости и правды.

- Ценностно-смысловая функция позволяет выстраивать траекторию построения волонтерской деятельности в образовательном учреждении. На ее основе строится организация целостного педагогического процесса, определяя цель, содержание, педагогические технологии, критериальные показатели эффективности педагогической работы в этом направлении

Таким образом, в соответствии с анализом педагогического потенциала волонтерской деятельности обучающихся вуза можно выделить следующие ее компоненты: деятельностный характер, личностную значимость и ценностно-смысловой аспект - высокую мотивацию к социально-полезной деятельности. Знание данных компонентов позволяет обосновать управление волонтерской деятельностью обучающихся вуза.

\section{ЛИТЕРАТУРА}

1. Ананьев Б.Г. Человек как предмет познания / Б.Г. Ананьев // Избранные психол. труды: в 2 т. Т.1. - Москва: Педагогика, 1980. - 232 с.

2. Болотова Л.В. Организация добровольческой деятельности как аспект вузовской подготовки будущих социальных работников: дис. канд. пед. наук: 13.00.02 / Л.В. Болотова. - Тамбов: [Б.и.], 2007. - 250 c.

3. Всеобщая Декларация Волонтеров. Электронный ресурс (https://cb-korablino.rzn.muzkult.ru/media/2018/09/02/1231340916/Vseobshhaya_Deklaraciya_ Volonterov.pdf)

4. Зеер Е.Ф. Психология профессионального развития: учебное пособие для вузов / Э.Ф. Зеер. - Москва: Академия, 2006. - 239 с.

5. Кон И.С. Психология юношеского возраста: проблемы формирования личности: учебное пособие / И.С. Кон.- Москва: Просвещение, 1976. - 175 с.

6. Кудринская Л.А. Добровольческий труд: опыт теоретической реконструкции: дис. доктора социологических наук: 22.00.03 / Л.А. Кудринская. - Москва: [Б. и.], 2006. -302 с.

7. Маковей Н.В. Педагогические условия подготовки студентов вузов к волонтерской деятельности: дисс. канд. пед. наук: 13.00.08 / Н.В. Маковей. - Благовещенск: [Б. и.], 2006. - 171 с.

8. Национальный проект «0бразование». Электронный ресурс (https://strategy24.ru/rf/education/projects/natsionalnyy-proekt-obrazovanie)

9. Певная М.В. Волонтерство как социальный феномен: управленческий ход: автореферат дисс. доктора социологических наук: 22.00.08 / М.В. Певная. Нижний Новгород: [Б. и.], 2016. -42 с.

10. Сикорская Л.Е. Педагогический потенциал добровольческой деятельности студенческой молодежи: концептуальные основы / Л.Е. Сикорская; под ред. В.А. Ситарова. - Москва: Московский гуманитарный университет, 2010. - 120 с.

11. Тернова Н.А. Работа с добровольцами / Н.А. Тернова. - Москва:УМКЦ РОКК, 2001. - 54 с.

12. Федеральный закон «0 внесении изменений в отдельные законодательные акты Российской Федерации по вопросам добровольчества (волонтерства)» 0т 05.02.2018 N 15-ФЗ Электронный ресурс (http://www.consultant.ru/document/cons_doc_LAW_289772/)

13. Циткилов, П.Я. Информационно - методические материалы по организации работы с волонтерами / П.Я. Циткилов // Социальная работа. - 2007. №5. - C. $58-60$. 